\title{
Colon volvulus displaced into the chest - right-sided posttraumatic hernia or congenital malformation?
}

\author{
Dorota Toliczenko-Bernatowicz, Wojciech Dębek, Ewa Matuszczak \\ Department of Pediatric Surgery, Pediatric Hospital of the Medical University of Bialystok, Poland
}

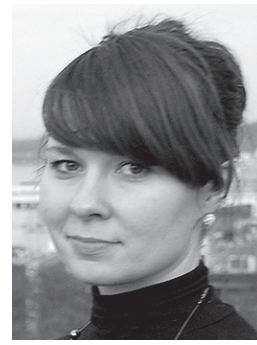

Kardiochirurgia i Torakochirurgia Polska 2016; 13 (2): 159-161

\begin{abstract}
We present the case of a 13.5-year-old girl who was admitted to the Pediatric Surgery Department from the Pediatric Department of a district hospital, where she stayed because of stomachache and vomiting. Interview revealed blunt injury of the epigastrium a week ago. Chest X-ray revealed a loss of the right diaphragmatic outline, irregular radiolucency on the right side of the chest, collapsed right lung and mediastinal displacement to the left. The patient was operated on, and the surgery revealed herniation of the intestines and half of the stomach into the defect of the right dome of the diaphragm. The patient made an uneventful postoperative recovery. A small innate defect of the diaphragm can remain asymptomatic and undiagnosed as long as there is no herniation of the abdominal organs into the chest.
\end{abstract}

Key words: diaphragmatic hernia, diaphragmatic rupture, trauma, children.

\section{Introduction}

Posttraumatic diaphragmatic rupture was first described by Sennertus in 1541, but successful surgical treatment was described much later, by Ralfi in 1886. A study performed by Carter et al. [1] revealed that most diaphragmatic ruptures are caused by blunt injuries (75\%), and the rest are the result of penetrating injuries. About $80-90 \%$ of diaphragmatic ruptures occur on the left side [2]. In the case of congenital diaphragmatic hernia, the defect is usually localized in the left posterolateral aspect of the muscle (Bochdalek's foramen) (85-90\% of cases) [3]. Right-sided congenital diaphragmatic herniation occurs in $5-10 \%$ of cases, and is usually associated with delayed presentation of non-specific symptoms [4].

\section{Case report}

A 13.5-year-old girl was admitted to the Pediatric Surgery Department from the Pediatric Department of the district hospital, where she was admitted the previous day,

\section{Streszczenie}

Autorzy pracy prezentują przypadek 13,5-letniej pacjentki przyjętej do Kliniki Chirurgii Dziecięcej z oddziału pediatrii innego szpitala, gdzie była hospitalizowana z powodu bólu brzucha i wymiotów. Ustalono nieznaczny tępy uraz brzucha przed około tygodniem. Na zdjęciu RTG klatki piersiowej i brzucha stwierdzono brak zarysu prawej kopuły przepony, nieprawidłowe przejaśnienie z poziomem płynu w obrębie prawej połowy klatki piersiowej oraz niedodmę płuca prawego i przesunięcie śródpiersia na stronę lewą. Pacjentkę zoperowano. Śródoperacyjnie stwierdzono uwięźnięcie jelita i części żołądka w świetle ubytku prawej części przepony. Przebieg okresu pooperacyjnego był niepowikłany. Niewielki wrodzony ubytek przepony stanowi potencjalne wrota przepukliny, jednak może on pozostawać nierozpoznany tak długo, jak nie ma przepukliny i nie daje ona objawów uwięźnięcia.

Słowa kluczowe: przepuklina przeponowa, uraz przepony, uraz, dzieci.

because of stomachache and vomiting. Thorough medical interview revealed blunt injury of the epigastrium caused by a ball a week ago, and an episode of stomachache and emesis a few months ago.

Physical examination revealed tenderness of the right epigastrium, significant reduction of the vesicular murmur on the right side of the chest and no peristalsis. Chest and abdomen X-ray examination revealed a loss of the right diaphragmatic outline, irregular radiolucency with a fluid level on the right side of the chest, collapsed right lung and mediastinal displacement to the left (Fig. 1).

The nasogastric tube was visualized inside the stomach, below the left diaphragmatic outline (Fig. 2). An additional computed tomography (CT) scan showed a small (several centimeters) defect of the right diaphragm and dislocation of the intestines and greater omentum into the chest and also liver displacement to the left (Fig. 3).

Aspartate transaminase (AST) and alanine transaminase (ALT) activity and the total concentrations of bilirubin 


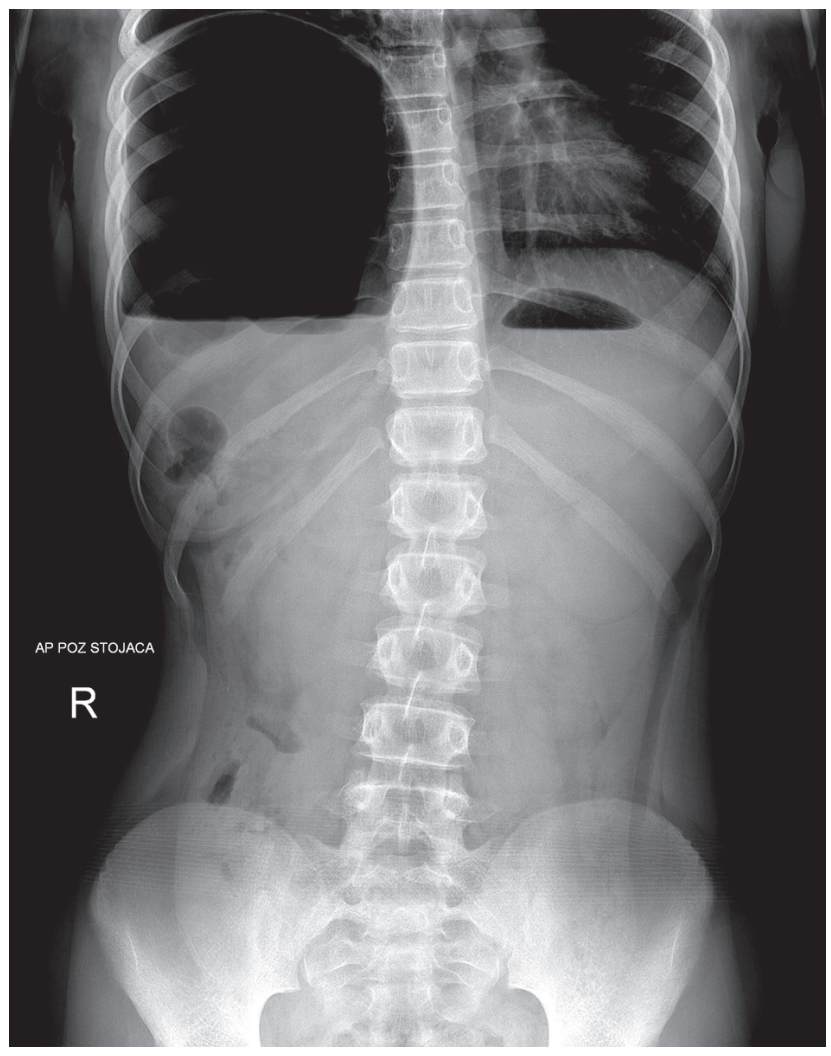

Fig. 1. Preoperative chest X-ray

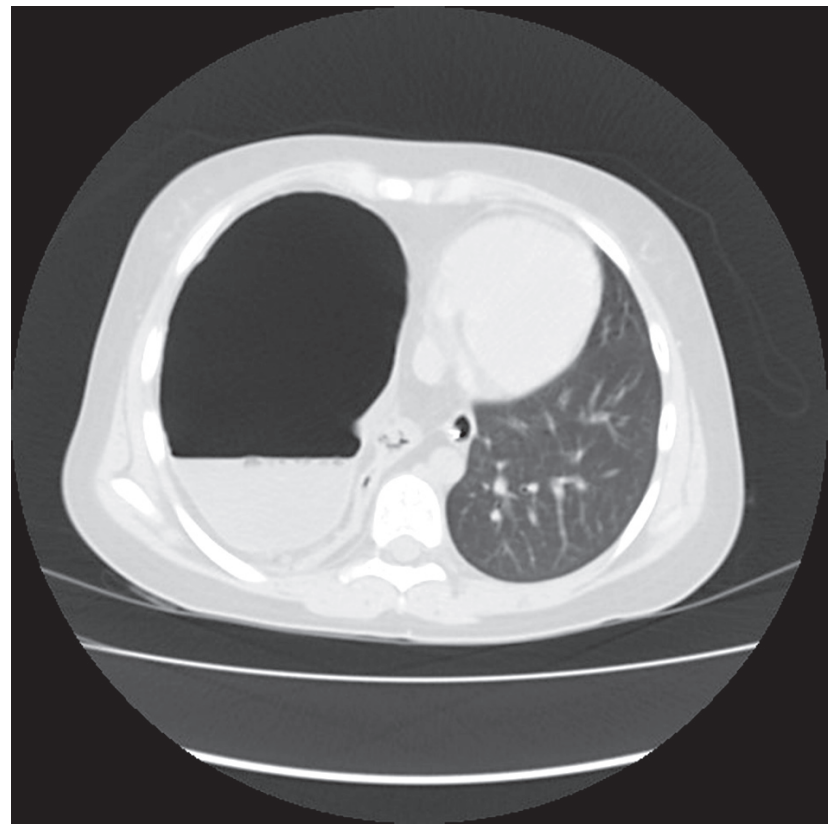

Fig. 3. Preoperative chest CT scan

and CRP were slightly elevated. Because of persistence of stomachache and volvulus symptoms, the patient was operated on. An upper midline laparotomy was used to access the abdominal cavity.

Herniation of the intestines and half of the stomach into the defect in the posterolateral part of the right dome of the

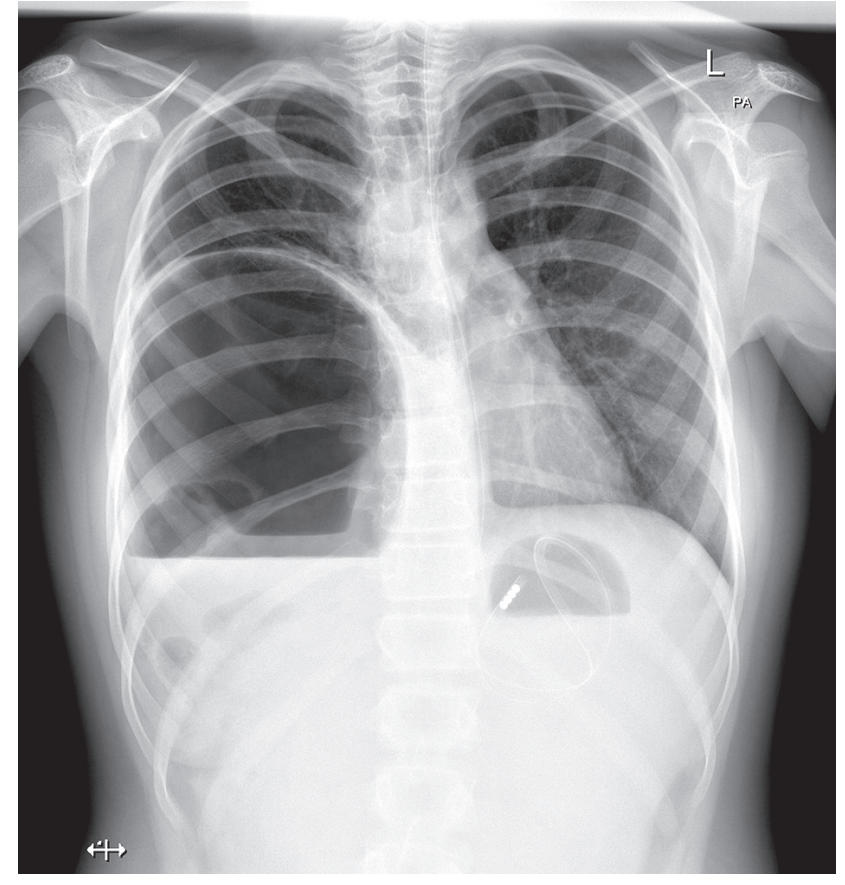

Fig. 2. Preoperative chest $\mathrm{X}$-ray with nasogastric tube

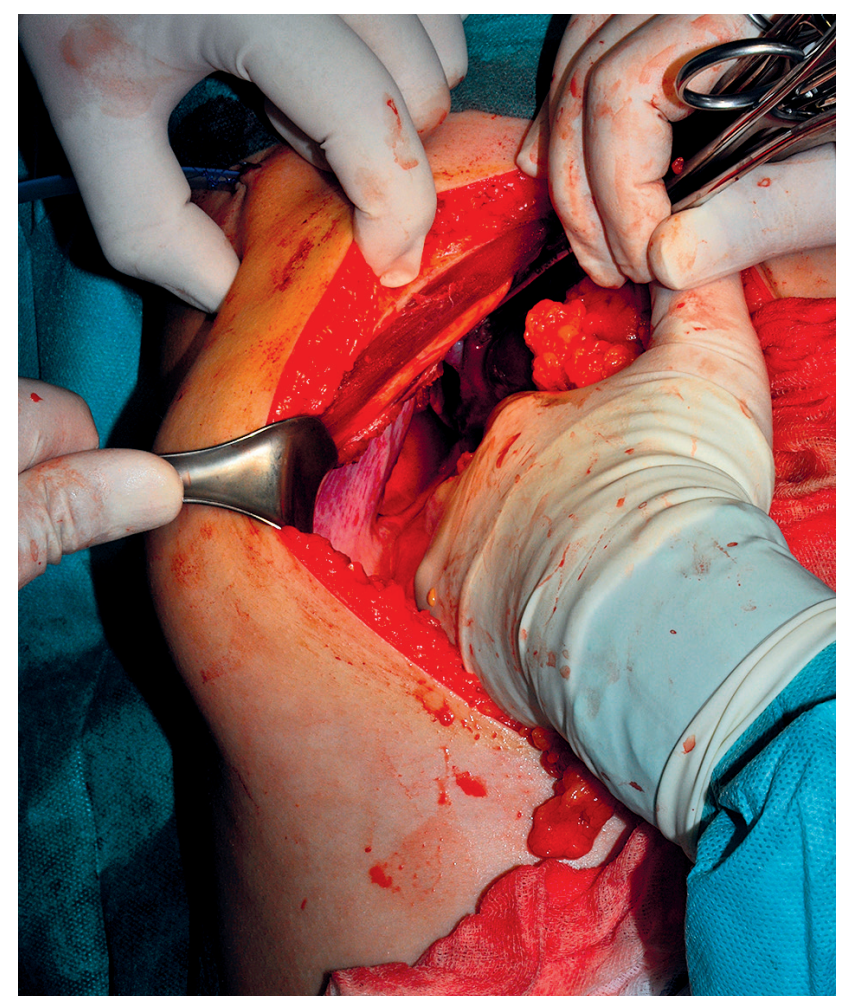

Fig. 4. The diaphragmatic defect during the operation

diaphragm was revealed. The diaphragm was cut along the course of the right diaphragmatic artery and the volvulus of half of the stomach, the transverse and a large part of the ascending and descending colon and greater omentum was released. The diaphragmatic defect seemed oval-shaped, and the edge of the aperture was smooth (Fig. 4). There 
were no signs of necrosis or gastrointestinal perforation or other internal organ injuries. The diaphragmatic defect was closed with one layer of interrupted non-absorbable sutures. Drainage of the right pleural cavity was placed in the thorax and the lung was expanded. The postoperative period was uneventful. The pleural drainage and bladder catheter were removed on the $2^{\text {nd }}$ postoperative day.

Chest X-ray performed on the $3^{\text {rd }}$ post operative day did not show any features of the diaphragmatic hernia. The patient commenced oral intake on the $3^{\text {rd }}$ postoperative day. Sutures were removed and the girl was discharged home on the $7^{\text {th }}$ postoperative day.

\section{Discussion}

Most posttraumatic diaphragmatic ruptures are located on the left side of the diaphragm and are the result of lower elasticity and vulnerability of this side, and also of the liver anatomy.

Right-sided diaphragmatic rupture is usually associated with massive injury (44-94\%) which results in liver, splenic and renal injuries and also pelvic and long bone fractures, large blood vessel injuries and head injuries [5].

A congenital diaphragmatic defect is usually located in the left part of the muscle. Only $5-10 \%$ of innate diaphragmatic defects are situated on the right side, and the symptoms are often atypical [6-8].

In our case the abdominal injury was mild, and it did not cause any specific internal organ injuries. The episode of stomachache and emesis a few months earlier might be a symptom of temporary herniation of the intestine into the congenital diaphragmatic defect.

In the case of a patient with suspicion of posttraumatic diaphragmatic rupture, $\mathrm{X}$-ray examination of the chest and abdomen, performed with a nasogastric tube, is considered to be the standard of care [9-11]. In our patient, the $X$-ray of the chest did not exclude the possibility of rightsided diaphragmatic rupture.

Only CT of the chest and abdomen enabled 3 dimensional reconstruction and appropriate assessment of anatomical structures. According to the literature, the main cause of delay in diagnosis of posttraumatic hernia is no sign of dislocation of abdominal organs into the chest in radiological examination [3].
In the literature there are reports that in $8 \%$ of cases, the diagnosis of diaphragmatic rupture is missed from 18 days up to 15 years. An innate diaphragmatic defect, which could be the cause of the diaphragmatic hernia, might remain undiagnosed, as long as there is no herniation of the abdominal organs into the chest. In our case, the small innate defect of the diaphragm became a gateway for diaphragmatic herniation and the relatively mild injury caused dislocation of abdominal contents into the thorax with volvulus of the dislocated colon.

\section{Conclusions}

The innate diaphragmatic defect in our patient could have remained asymptomatic and undiagnosed without the posttraumatic herniation of the abdominal organs into the chest and subsequent volvulus.

\section{Disclosure}

Authors report no conflict of interest.

\section{References}

1. Shana LK, Kennedy RF, Heneghan WD. Rupture of the diaphragm resulting from blunt trauma in children. Can J Surg 1997; 20: 553-556.

2. Khan TR, Rawat J, Maletha M, Singh S, Reshid KA, Wakhlu A, Kereel SN. Traumatic diaphragmatic injuries in children, do they really mark the severity of injury; our experience. Ped Surg Int 2009; 25: 595-599.

3. Lal S, Kailasia Y, Chouhan S, Gaharwar APS, Shrivastora GP. Delayed presentation of post traumatic diaphragmatic hernia. J Surg Case Rep 2011; 7: 6.

4. Rattan KN, Narang R, Rohilla S, Maggu S, Dhaulakhandi DB. Thirteen years' experience of diaphragmatic injury in children from the Post Graduate Institute of Medical Sciences (PGIMS), Rohtak, India. Malays J Med Sci 2011; 18: 45-51.

5. Friedhender E, Tsarouhas N. Traumatic diaphragmatic rupture in pediatric patient: a case report. Pediatr Emerg Care 2003; 19: 340-342.

6. Moore CM, Mander BJ, Raja MA. A case of congenital eventration of the diaphragm mimicking traumatic diaphragmatic rupture. Injury 2001; 32: 508-509.

7. Balimberti A, Casagrande A, Compagnoni BM, Sasonetti G, Rusconi A, Grassi M, Ferrante F. Late post-traumatic diaphragmatic hernia: unusual cause of colonic occlusion. Chir Ital 2001; 53: 551-554.

8. Iochum S, Ludif T, Walter F, Sebbag H, Grosdidier G, Blum AG. Imaging of diaphragmatic injury: a diagnostic challenge? Radiographics 2002; 22: 116-201.

9. Boulanger BR, Milzman DP, Rosati C, Rodriguez A. A comparison of right and left blunt traumatic rupture. J Trauma 1993; 35: 255-260.

10. Reber PU, Schmied B, Seiler CA, Baer HU, Patel AG, Buchler MW. Missed diaphragmatic injuries and their long - term sequelae. J Trauma 1998; 44: 183-188.

11. Crandall M, Popowich D, Shapiro M. Posttraumatic hernias: historical overview and review of the literature. Am Surg 2007; 73: 845-850. 